\title{
Characteristics of immersion freezing nuclei at the South Pole station in Antarctica
}

\author{
K. Ardon-Dryer ${ }^{1,2}$, Z. Levin ${ }^{1,3}$, and R. P. Lawson ${ }^{4}$ \\ ${ }^{1}$ Department of Geophysics and Planetary Science, Tel Aviv University, Israel \\ ${ }^{2}$ The Porter School of Environmental Studies, Tel Aviv University, Israel \\ ${ }^{3}$ Energy, Environment and Water Research Center, The Cyprus Institute, Nicosia, Cyprus \\ ${ }^{4}$ SPEC Incorporated, Boulder, Colorado, USA
}

Received: 14 November 2010 - Published in Atmos. Chem. Phys. Discuss.: 5 January 2011

Revised: 4 April 2011 - Accepted: 21 April 2011 - Published: 29 April 2011

\begin{abstract}
The effectiveness of aerosols as immersion freezing nuclei at the South Pole station was investigated during January and February 2009 using the FRIDGE-TAU. The analysis consisted of testing the freezing temperature of about 100-130 drops per sample containing aerosols collected at ground level and on a balloon lifted to different heights. All the drops froze between $-18^{\circ} \mathrm{C}$ and $-27^{\circ} \mathrm{C}$. The temperature in which $50 \%$ of the drops froze occurred at $-24^{\circ} \mathrm{C}$, while nuclei concentration of $1 \mathrm{~L}^{-1}$ at $-23^{\circ} \mathrm{C}$ was calculated. Meteorological conditions such as wind speed, ice precipitation as well as the trajectories of the air masses affected the ice nuclei concentrations. Higher concentrations were observed on days when the winds were stronger or when the air mass originated from the sea.
\end{abstract}

\section{Introduction}

Much attention has been given to condensation nuclei (CN) characteristics in the Antarctic continent (Saxena, 1983; Gras et al., 1985; DeFelice, 1996; DeFelice et al., 1997), yet the characteristics of ice-forming nuclei, their origin, composition and concentrations have only seldom been studied (Bird et al., 1961; Bigg and Hopwood, 1963; Kumai, 1976; Saxena and Weintraub, 1988; Junge and Swanson, 2008). Most of the above studies were conducted along the coast of Antarctica and only a very few reported on measurements at the South Pole (e.g. Kumai, 1976).

Different types of instruments and methods have been used to measure ice nuclei (IN) in Antarctica. Some measurements were conducted by sampling aerosols on filters and analyzing their ice nucleating properties by exposing them

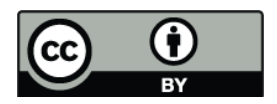

Correspondence to: Z. Levin (zevlev@ post.tau.ac.il) in the laboratory to water saturation conditions at different sub-zero temperatures (Bigg, 1973). Others brought outside air into a mixing cold chamber and counted the number of ice crystals that fell into a sucrose solution (Bigg and Hopwood, 1963; Bigg, 1990). Some reported on ice nuclei concentrations by counting the number of supercooled drops that froze in a free-falling freezing tube (Junge and Swanson, 2008). Saxena and Weintraub (1988) tested the effectiveness of aerosols as ice nuclei by using the drop freezing technique. All the above mentioned methods analyzed the effectiveness of the aerosols as immersion freezing or as condensationfreezing nuclei.

Bigg and Hopwood (1963) reported on ice nuclei concentrations at McMurdo station located near the coast of Antarctica. They found that freezing occurred between $-14^{\circ}$ to $-26^{\circ} \mathrm{C}$, with concentrations of $0.5-13 \mathrm{~L}^{-1}$ of active nuclei at $-20^{\circ} \mathrm{C}$. In contrast to more recent observations suggesting that effective ice nuclei have sizes larger than about $0.1 \mu \mathrm{m}$, Bigg and Hopwood (1963) found that most of the nuclei had diameters between $0.01 \mu \mathrm{m}$ and $0.1 \mu \mathrm{m}$. Bigg (1973) measured ice nuclei concentrations at $-10,-15$ and $-20^{\circ} \mathrm{C}$ with mean concentrations of $1-5 \times 10^{-3}, 10-20 \times 10^{-3}$, $0.1 \mathrm{~L}^{-1}$, respectively. Saxena and Weintraub (1988) used drop freezing measurements at Palmer station over the temperature range of $-5^{\circ} \mathrm{C}$ to $-17^{\circ} \mathrm{C}$. They reported on the presence of high concentrations of ice nuclei $\left(0.01\right.$ to $\left.10 \mathrm{~L}^{-1}\right)$ even at temperatures as high as -5 to $-7{ }^{\circ} \mathrm{C}$. They also reported finding good correlation between ice nuclei concentrations and the presence of Potassium, Silicon and Zinc.

Carpenter et al. (2000) and Warren and Hudson (2003) reported on the existence of bacteria in the South Polar snow. However, their effectiveness as IN is still unclear. Junge and Swanson (2008) suggested that immersion freezing of marine psychro-active bacteria and viruses would not be important for heterogeneous ice nucleation processes in polar clouds nor for the formation of sea ice, because they would

Published by Copernicus Publications on behalf of the European Geosciences Union. 


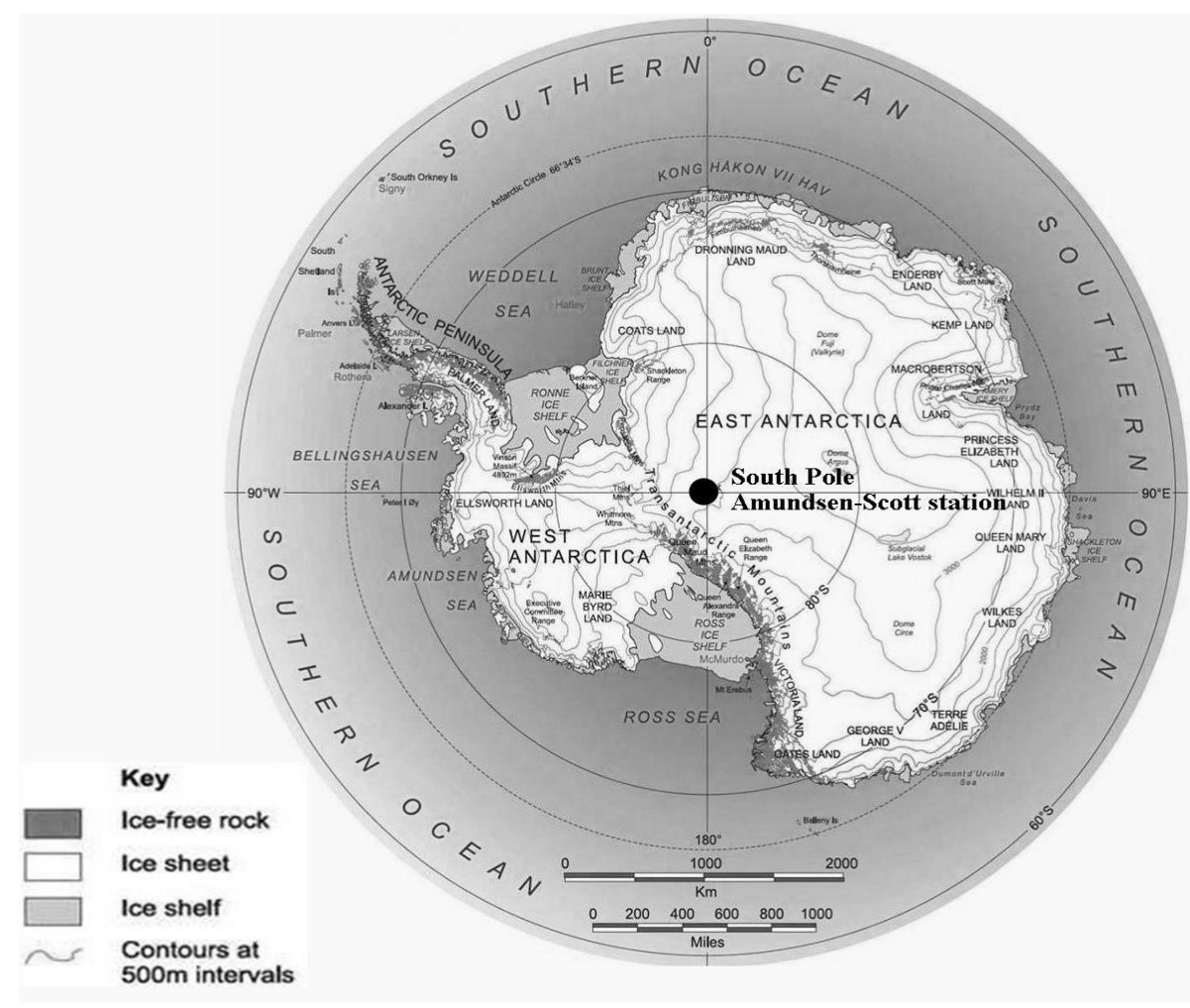

Fig. 1. Location of the Amundsen-Scott station at the South Pole, in Antarctica, marked in black circle (Geology, 2010 with modification).

nucleate ice at temperatures very close to the homogeneous nucleation temperature $\left(-42.2 \pm 0.3^{\circ} \mathrm{C}\right)$.

The relative contribution of mineral dust aerosols, which are known to be good ice nuclei, to the aerosol population in Antarctica, is still unclear. Bird et al. (1961) claims that dust of land origin cannot generally contribute to nucleus concentration in the Southern Hemisphere. Iriondo (2000) suggested that mineral dust particles can be transported from Patagonia (South America) to western Antarctica, which seems to agree with Kumai (1976) who reported that $85 \%$ of the snow crystals had nuclei in them which were mainly clay minerals and sodium chloride particles. The clay mineral nuclei consisted of $20 \%$ Illite, $8 \%$ Kaolin, $4 \%$ Halloysite, $3 \%$ Vermiculite, and $24 \%$ other related minerals. Similar concentration were found in Patagonia deserts (Johnson et al., 2010).

The objective of this paper is to report on ice nuclei measurements in a remote pristine region of Antarctica such as the South Pole station. Our experiment was a small piggybacked project on a larger project which lasted two weeks and was primarily focused on balloon cloud particle measurements (Lawson et al., 2011). The experiment was unique because it was the first time that a balloon with a $15 \mathrm{~kg}$ microphysical package had been flown in clouds at the South Pole.

\section{The characteristics of the research area}

The measurements were conducted during January and February 2009 at the Amundsen-Scott station at the geographical South Pole (Latitude $89^{\circ} 59.77^{\prime} \mathrm{S}$, Longitude $92^{\circ} 1^{\prime}$ E, Fig. 1) on a polar plateau at an altitude of $2850 \mathrm{~m}$ (for more information about the campaign see Lawson et al., 2011). The weather is uniformly cold and dry (Hogan, 1979). Its average barometric pressure is about $680 \mathrm{mb}$ (Hogan and Barnard, 1978). The surface circulation on the polar plateau is dominated by a weak gradient wind, with slight katabatic reinforcement (Hogan et al., 1982). Surface winds generally swing from north $\left(0^{\circ}\right.$ Longitude) to northwesterly $\left(315^{\circ}\right.$ Longitude) (Bigg, 1980). Frontal type storms are very rare in the South Pole plateau (Hogan, 1975a). The summer time is characterized by clear skies with occasional occurrence of ice saturated layers just above the surface (Egan and Hogan, 1986). Most of the clouds are cirrus and altostratus; liquid precipitation is unknown but ice crystal precipitation is relatively common (Hogan, 1975b). It should be noted that using a cloud particle imager (Lawson et al., 2001) during this campaign, Lawson et al. (2011) observed liquid and solid particles in clouds from about 250 to $500 \mathrm{~m}$ above the surface. The in situ observations of water drops were correlated with a distinctive Lidar pattern that showed an intense backscatter signature. Their preliminary investigation of the Lidar data shows that the mixed-phase signature observed is not an 


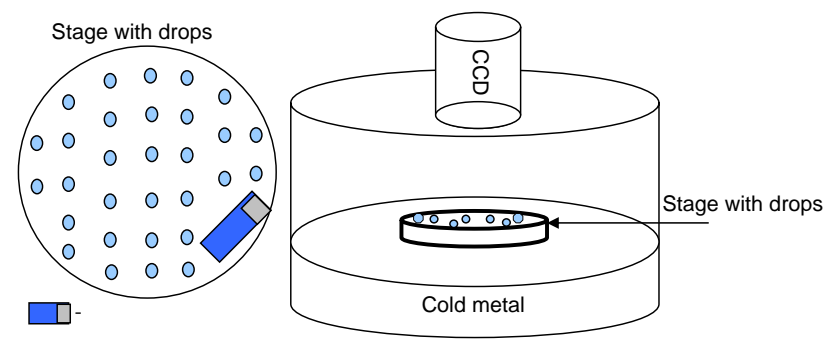

Fig. 2. Schematic diagram of the immersion freezing method.

anomaly, and that the signature is even found in clouds aloft when the surface temperature is $-50{ }^{\circ} \mathrm{C}$.

The South Pole is characterized mostly by very small aerosols (Bigg, 1980; Shaw, 1980; Park et al., 2004). The submicron aerosol particles appear to be mainly sulfates (Deshpande and Kamra, 2004) in the form of sulfuric acid, ammonium bisulphate or ammonium sulfate (Bigg, 1980; Bigg et al., 1984). Bodhaine et al. (1988) found black carbon at the South Pole, which they attribute to local pollution. Even sea salt particles have been found at the South Pole (Parungo et al., 1981; Hogan et al., 1984), although the station is located $1250 \mathrm{~km}$ away from the ocean (Kumai, 1976). Some of the common elements found in the Antarctic aerosol are iron, potassium, silicon, calcium, aluminum, sulfur and titanium (Cadle et al., 1968; Parungo et al., 1981; Saxena and Weintraub, 1988).

According to Hogan et al. (1982) a few times a year, large storm systems intrude far enough south to cause moist flow up the glacial slopes to the South Polar Plateau. This flow brings relatively warm moist aerosol laden air to the South Pole. As this air cools toward inland, ice crystals form, precipitate to the surface removing water and scavenge aerosols from the lowest layers.

\section{Method of analysis}

Twelve filter samples were collected; nine from the rooftop and three from a balloon (see Table 1) the inlet of the filter holder was positioned with the wind to its back. The aerosols were sampled on Nitrocellulose filters with diameter of 47 $\mathrm{mm}$ and $0.45 \mu \mathrm{m}$ pore size which were held in a standard Millipore plastic holder at a flow rate of $8 \mathrm{LPM}$. The inlet diameter was $5.5 \mathrm{~mm}$, thus the air velocity at the inlet was about $5.6 \mathrm{~m} \mathrm{~s}^{-1}$. The effectiveness of the sampled aerosols as immersion freezing was measured using a drop freezing technique.

The immersion freezing measurements were conducted using the FRIDGE-TAU (FRankfurt Ice-nuclei Deposition freezinG Experiment, the Tel Aviv University version) chamber (Fig. 2). This chamber which is usually used for measuring ice nucleation by deposition or by condensation freezing (Bundke et al., 2008; Klein et al., 2010) was used here to
Table 1. Description of sampled filters.

\begin{tabular}{llrl}
\hline $\begin{array}{l}\text { Filter } \\
\#\end{array}$ & $\begin{array}{l}\text { Time of } \\
\text { measurement } \\
\text { (UTC) }\end{array}$ & $\begin{array}{r}\text { Volume of air } \\
\text { sampled } \\
\text { (L) }\end{array}$ & $\begin{array}{c}\text { Filter } \\
\text { Location }\end{array}$ \\
\hline 1 & 28 Jan 2009 & 344 & Rooftop \\
2 & 28 Jan 2009 & 327 & Rooftop \\
3 & 29 Jan 2009 & 319 & Rooftop \\
4 & 29 Jan 2009 & 450 & Rooftop \\
5 & 29 Jan 2009 & 327 & Balloon \\
6 & 29 Jan 2009 & 245 & Balloon \\
7 & 29 Jan 2009 & 245 & Balloon \\
8 & 30 Jan 2009 & 499 & Rooftop \\
9 & 30 Jan 2009 & 1317 & Rooftop \\
10 & 31 Jan 2009 & 1579 & Rooftop \\
11 & 1 Feb 2009 & 1873 & Rooftop \\
12 & 2 Feb 2009 & 2495 & Rooftop \\
\hline
\end{tabular}

determine the temperature at which freezing of drops containing aerosols took place.

Each filter containing the collected aerosols was placed in $10 \mathrm{ml}$ of double distilled water (resistivity of $18.2 \mathrm{megohm} \mathrm{cm}^{-1}$ ). The aerosols were then removed from the filter by ultrasonic shaker. The resulting mixture of water and aerosols was the source of the drops tested for immersion freezing. Each test consisted of about 120 drops ( $2 \mu \mathrm{l} ; 1.6 \mathrm{~mm}$ diameter) that were placed on the temperature controlled stage in the FRIDGE-TAU. A thin layer of Vaseline was first put on the stage in order to prevent ice from forming on the surface during cooling. This is because sometimes very thin ice dendrites on the substrate start to grow by vapor deposition from the perimeter of some of the frozen drops, reaching and freezing some of their neighbors, thus affecting the measurements.

The temperature of the cooling stage was lowered at a constant rate of $1^{\circ} \mathrm{min}^{-1}$ and the number of drops that froze at each temperature was recorded by a CCD camera.

In some cases (e.g. filter 4, 8-12), the filters were cut in half, due to the large volume of air that had been sampled through them. Some of the sections that had not been used to analyze ice nuclei were saved for elemental analysis of individual aerosols in an Environmental Scanning Electron Microscope, ESEM (filters: 4, 9 and 10). In addition to the exposed filters, an unexposed filter was sent back from the South Pole for comparative analysis. Unfortunately, we discovered that the blank filter was contaminated in the South Pole Laboratory. Instead we tested two blank filters from the same batch that were left for this purpose in our laboratory. The procedure for testing freezing with these filters was identical to the exposed filters. The average of cumulative drop freezing on these filters is presented in Fig. 3. 


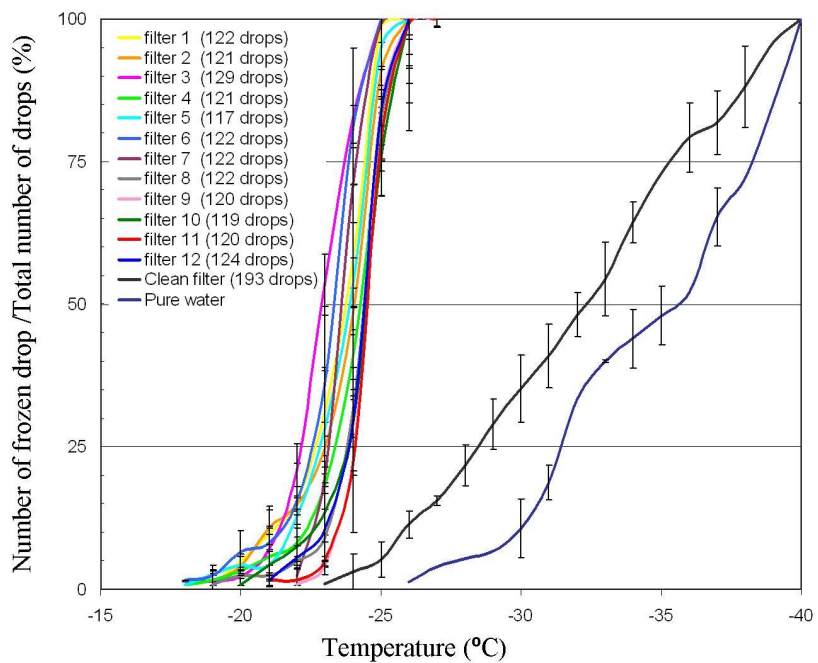

Fig. 3. The cumulative freezing spectrum of all the South Pole samples and the average spectrum of freezing temperature from clean blank filters and pure water. The bars represent the standard deviation.

\section{Results and discussion}

Twelve samples containing a total of 1459 drops were analyzed. The analysis was carried out between 0 to $-27^{\circ} \mathrm{C}$ within which all the drops froze (Fig. 3). Most drops in most samples began to freeze only at $-18^{\circ} \mathrm{C}$. The freezing occurred at warmer temperatures as compared to water drops taken from pure water. It is apparent that although freezing of drops started at $-18^{\circ} \mathrm{C}$ most froze at temperatures lower than $-20^{\circ} \mathrm{C} .50 \%$ of the drops in all the samples froze between -23 to $-24.5^{\circ} \mathrm{C}$. The average temperature in which $50 \%$ of the drops froze occurred at $-24^{\circ} \mathrm{C}$, much warmer than reported by Junge and Swanson (2008) where near homogeneous freezing temperatures were observed for specific bacterial isolates.

Drop freezing experiments using water with blank filters revealed that most of the drops froze at temperatures well below those from the exposed filters. However, there was a small overlap between the blank filters and the others from $-23^{\circ} \mathrm{C}$ to $-27{ }^{\circ} \mathrm{C}$ (see Fig. 3). In order to calculate the concentrations of $\mathrm{FN}$ in the air the fraction of drops from the blank that froze at each temperature was deducted from the corresponding frozen drops on the sampled filters. The effect on the calculated concentrations was minimal (from $\sim 0.06 \%$ to $5.9 \%$ over the temperature range in the experiment).

Equation (1) is constructed from the original equation of Vali (1971). The equation is composed of two parts: the first is an integration of the differential probability that a drop will freeze at temperatures between $\theta$ and $\theta-\Delta \theta$ due to the presence of a single active nucleus in it over the temperature range from $0{ }^{\circ} \mathrm{C}$ to $\theta$ The result of the integration is the cumulative nucleus concentration $K^{\prime}(\theta)$, which represents the

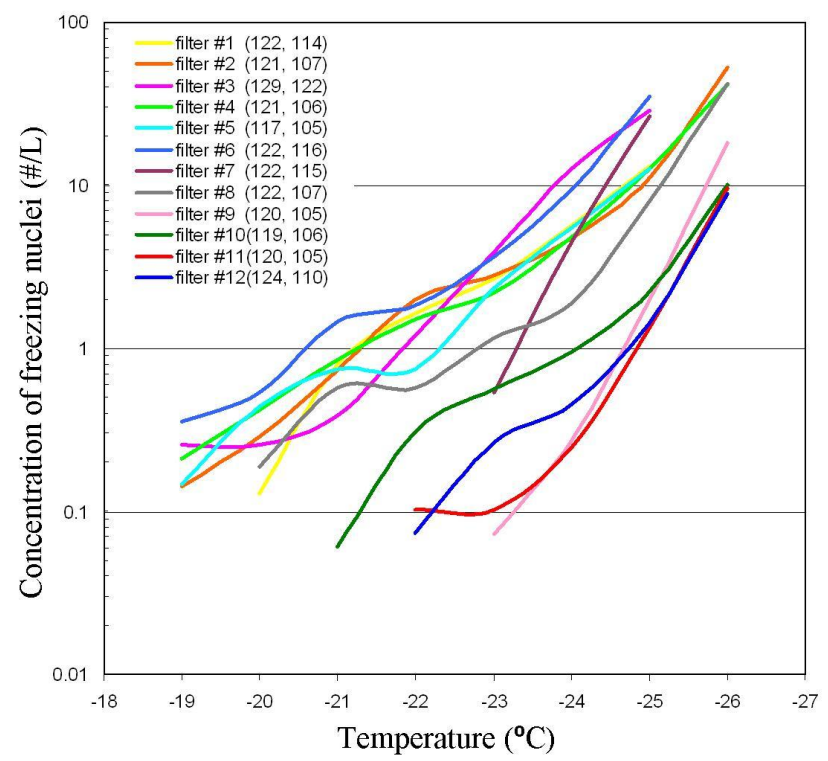

Fig. 4. Concentration of Freezing Nuclei in the air for the different samples calculated from Eq. (1). The first number in the parenthesis represents the number of drops used in the experiment and the second is the one used for the present calculations after deducting the drops that froze on the blank filters (see text for explanation).

number of nuclei active at all temperatures warmer than $\theta$. In order to obtain the actual concentrations of ice nuclei in the sampled air, consideration must be given to the total air sampled. This is presented in the last part of the equation.

$K^{\prime}(\theta)=\frac{1}{V} \times\left[\ln \left(N_{0}\right)-\ln (N(\theta)] \times \frac{x}{y}\right.$

$K^{\prime}(\theta)$ - Cumulative concentration of FN in the air active at temperature $\theta\left(\mathrm{L}^{-1}\right)$

$V$ - Volume of drop (L)

$N_{o}$ - Total number of drops measured

$N(\theta)$ - Number of unfrozen drops at temperature $\theta$

$x$ - The volume of water used to remove the aerosols from the filter (L)

$y$ - The volume of air sampled through the filter (L)

The concentration of freezing nuclei in the air calculated for the different samples between -19 to $-26^{\circ} \mathrm{C}$ varied from $0.1 \mathrm{~L}^{-1}$ to $53 \mathrm{~L}^{-1}$, respectively, as can be seen in Fig. 4. As expected, the number of active nuclei increases as the temperature decreases. A concentration of $1 \mathrm{~L}^{-1}$ was observed in all the filters between $-21^{\circ} \mathrm{C}$ to $-25^{\circ} \mathrm{C}$.

\subsection{Measurements of freezing nuclei from the balloon}

Since the balloon carried many other instruments, the sampling for ice nuclei measurements received lower priority and thus only one day was devoted to this task. 
Table 2. The filters used for calculating the average FN concentrations based on the day of measurement.

\begin{tabular}{lcccccc}
\hline UTC time & 28 Jan 2009 & 29 Jan 2009 & 30 Jan 2009 & 31 Jan 2009 & 1 Feb 2009 & 2 Feb 2009 \\
\hline Filter \# & 1,2 & 3,4 & 8,9 & 10 & 11 & 12 \\
\hline
\end{tabular}

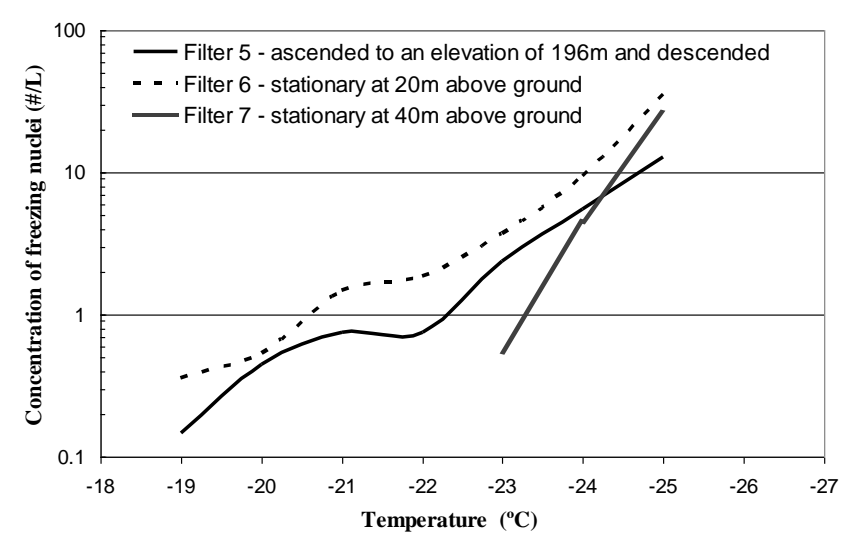

Fig. 5. Concentration of freezing nuclei from samples collected on the balloon.

This limitation allowed for only three balloon samples (filters $5,6,7)$ as compared to eight samples from the rooftop (filters $1-4 ; 8-12$ ). One sample (filter 5) was collected as the balloon ascended to $196 \mathrm{~m}$ (below the top of the mixed layer of 200-300 m as reported by Argentini et al., 2005) and then descended to the surface. The second and third samples (filters 6 and 7) were collected when the balloon remained stationary at $20 \mathrm{~m}$ and $40 \mathrm{~m}$ above ground, respectively. Figure 5 shows that the concentrations of ice nuclei collected at $20 \mathrm{~m}$ were higher than those measured during ascend and descend of the balloon. The lower FN concentrations at the higher altitude (filter 5) suggest that most of the effective FN originate from the surface or are transported from long distances at the boundary layer. As will be discussed below, we could not rule out the possibility that blowing ice crystals were collected on the balloon samples. This may partly explain the higher concentrations of $\mathrm{FN}$ found at $20 \mathrm{~m}$ as compared to the higher levels. The fact that the FN concentrations on filter 5 (ascended to $196 \mathrm{~m}$ and then descended) were higher than on filter 7 (stationary at $40 \mathrm{~m}$ ) is simply due to the fact the balloon spent a fraction of time below the $40 \mathrm{~m}$ level as it ascended and descended, thus collection aerosols from the lower altitudes.

Since most of the measurements were carried out from the rooftop and since the difference between filters 5 and 6 is small, most of the rest of the analysis will deal only with the rooftop measurements.

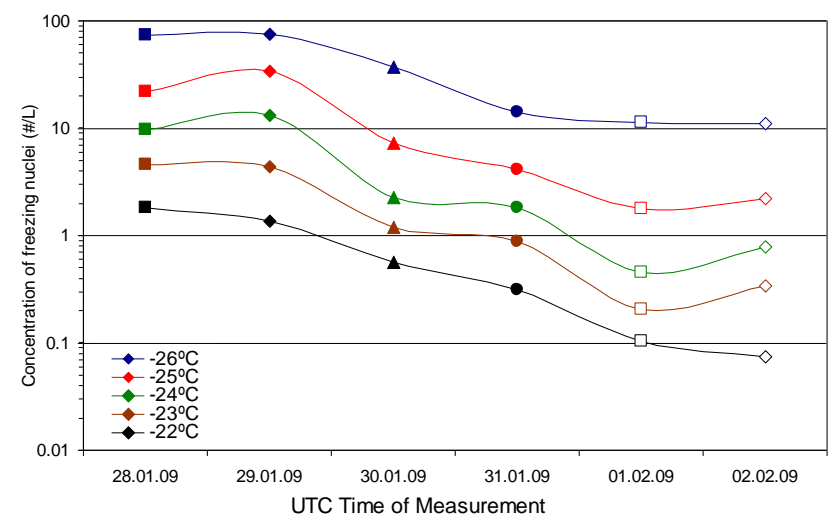

Fig. 6. Concentrations of Freezing Nuclei at different temperatures for the rooftop measurements on different days of the campaign. Each day is represented by a different symbol, and each temperature is represented by a different color.

\subsection{Measurements of freezing nuclei from the rooftop}

Figure 6 represents the average concentrations of $\mathrm{FN}$ at a number of temperatures on each day of the campaign based on the measurements of the filters shown in Table 2. As can be seen, at the beginning of the campaign (28-29 January 2009), larger concentrations of FN were found at all temperatures between $\sim-22{ }^{\circ} \mathrm{C}$ to $-26^{\circ} \mathrm{C}$. With time, the concentration of FN decreased by about one order of magnitude at all temperatures. In order to understand these changes in FN concentration we decided to investigate the possible connection with the meteorological conditions (local and historical) that existed at the time of the campaign.

Based on the meteorological data collected at the measuring site it appears that the aerosols samples were collected under different meteorological conditions. One local meteorological condition that could have had an effect on the FN concentration is wind speed. Each filter sample was collected under different wind speeds, as can be seen in Table 3. High correlation between wind speed and FN was found for all measured temperatures (Fig. 7a). Similarly, the correlation of wind speed with total aerosol concentrations was high also (Fig. 7b). It should be noted that the aerosol concentrations shown in Table 3 refer to total aerosols greater than $0.01 \mu \mathrm{m}$ (measured by the condensation particle counter TSI 3760). Most of these aerosols may not be so relevant for the FN measurements because they are much smaller than the expected 
Table 3. Average surface meteorological conditions during sampling.

\begin{tabular}{lrrrrrr}
\hline $\begin{array}{l}\text { filter } \\
\text { number }\end{array}$ & Temperature & $\begin{array}{r}\text { Ambient } \\
\text { pressure } \\
(\mathrm{hPa})\end{array}$ & $\begin{array}{r}\text { Wind } \\
\text { speed } \\
\left(\mathrm{m} \mathrm{s}^{-1}\right)\end{array}$ & $\begin{array}{r}\text { Wind } \\
\text { direction } \\
\left({ }^{\circ}\right)\end{array}$ & $\begin{array}{r}\text { RH in } \\
\text { the air } \\
(\%)\end{array}$ & $\begin{array}{r}\text { Aerosol number } \\
\text { concentration } \\
>0.01 \mu \mathrm{m}\left(\mathrm{cm}^{-3}\right)\end{array}$ \\
\hline 1 & -25.0 & 680.2 & 9.7 & 5.5 & 98.507 & 1864.3 \\
2 & -25.2 & 680.0 & 10.3 & 5.0 & 98.877 & 1996.3 \\
3 & -26.5 & 680.0 & 8.6 & 10.4 & 97.879 & 1978.0 \\
4 & -27.0 & 679.9 & 7.5 & 16.2 & 98.245 & 1748.5 \\
5 & -27.2 & 679.5 & 6.5 & 21.0 & 98.268 & 1464.7 \\
6 & -26.6 & 679.0 & 8.0 & 23.3 & 97.932 & 1757.7 \\
7 & -26.8 & 678.8 & 6.4 & 28.1 & 96.258 & 1704.2 \\
8 & -31.3 & 680.4 & 4.7 & 353.4 & 97.139 & 335.4 \\
9 & -32.6 & 683.4 & 5.4 & 76.0 & 98.045 & 545.3 \\
10 & -33.1 & 682.9 & 4.1 & 92.5 & 97.353 & 520.6 \\
11 & -27.5 & 685.0 & 5.6 & 59.3 & 97.367 & 1152.2 \\
12 & -30.6 & 689.1 & 2.4 & 298.9 & 82.720 & 1308.5 \\
\hline
\end{tabular}

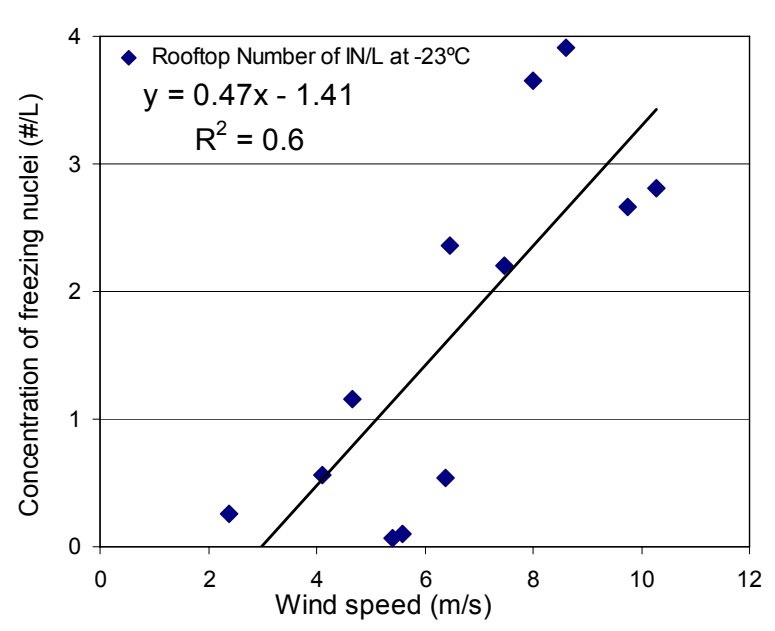

Fig. 7a. Concentration of freezing nuclei at $-23^{\circ} \mathrm{C}$ as a function of wind speed.

size of the ice nuclei (e.g. DeMott et al., 2010), however, this was the only reliable and available data on aerosol size and concentration.

Lawson et al. (2006) reported that at the South Pole Station blowing snow is observed when the wind speed exceeds about $4 \mathrm{~m} \mathrm{~s}^{-1}$. Knuth et al. (2010) measured a threshold of between 6.6 to $7.5 \mathrm{~m} \mathrm{~s}^{-1}$ at $10 \mathrm{~m}$ height for blowing dry snow at the Ross Ice Shelf. The threshold for blowing wet snow was higher at 8.5 to $9.6 \mathrm{~m} \mathrm{~s}^{-1}$. Threshold for blowing snow on the Ross Ice Shelf is likely to be different than at the South Pole since the type of precipitation is quite different. For our purpose here $6 \mathrm{~m} \mathrm{~s}^{-1}$ was chosen as a threshold for blowing snow. Based on that, our filter samples were divided into two groups, above and below the wind speed of $6 \mathrm{~m} \mathrm{~s}^{-1}$. For example, filters 1-4 were exposed to higher

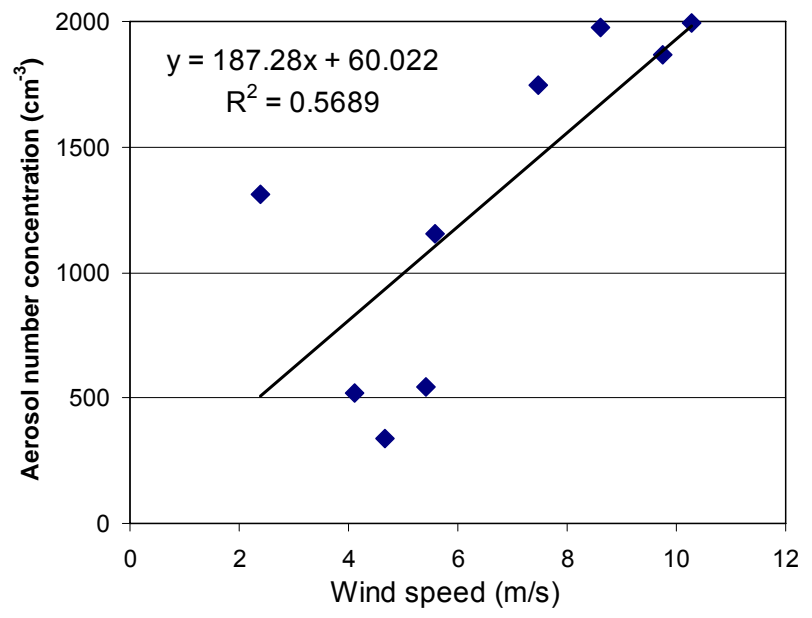

Fig. 7b. Concentration of aerosols $>0.01 \mu \mathrm{m}$ as a function of wind speed.

wind speed (average of $9 \mathrm{~m} \mathrm{~s}^{-1}$ ) and had $2.9 \mathrm{~L}^{-1}$ at $-23^{\circ} \mathrm{C}$. Filters $8-12$, which were exposed to lower average wind speeds of about $4.4 \mathrm{~m} \mathrm{~s}^{-1}$ had only $0.4 \mathrm{~L}^{-1}$ at $-23^{\circ} \mathrm{C}$. One explanation for this observation was based on the suggestion by Hogan (1979) who showed that strong winds in the South Pole increased the mixing of air near the surface, leading to higher concentration of larger particles at higher elevations, implying higher concentrations of FN. During the sampling time of filter 9-11, the station was affected by falling ice crystals and broken clouds that occurred from $30 \mathrm{Jan}-$ uary 2009 to 1 February 2009 (see decrease in FN concentration in Fig. 6). These falling ice crystals undoubtedly scavenged aerosols in the lower atmosphere, thus reducing the measured FN concentrations. The possibility that sublimated ice crystals in the air affected the ice nuclei measurements 

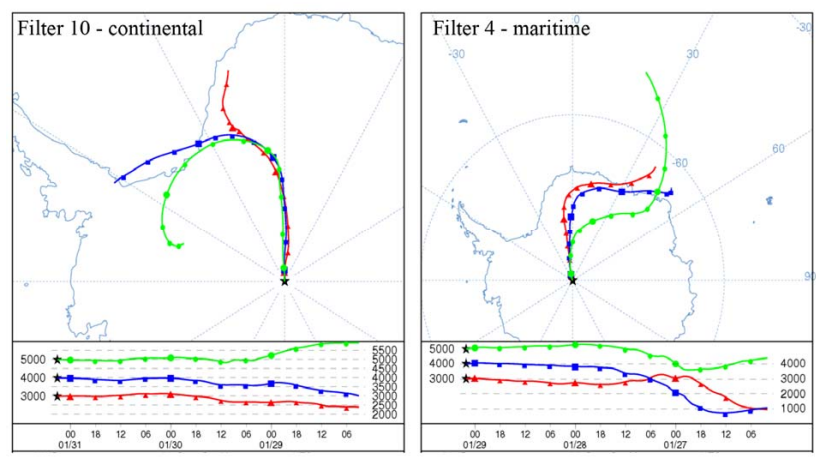

Fig. 8. Two examples of back trajectories of continental air collected on filter 10 and maritime air that was sampled on filter 4 . The maps show the trajectory that the air parcels travel before reaching the station, located at an altitude of about $3000 \mathrm{~m}$ a.s.l. The vertical projection for air arriving from 3000, 4000 and $5000 \mathrm{~m}$ is shown. Source: http://www.arl.noaa.gov.

was ruled out because the relative humidity was far above ice saturation. The only possible effects could be the collection of some of the ice crystals on the filters, which sublimated later, leaving the ice nuclei on the filters. However, the chance for this to happen was considered low because of (a) the sampler was facing away from the average wind direction, thus making it difficult for the ice crystals to enter the inlet and (b) the inlet air speed was about $5.6 \mathrm{~m} \mathrm{~s}^{-1}$, which implies that we under-sampled the large particles (see Su and Vincent, 2004) and reduced the potential for collecting blowing ice crystals. However, we cannot rule out the possibility that on the balloon ice crystals were collected. This is because the position of the inlet could not be fixed with respect to the wind direction.

In addition to the effects of the local meteorological conditions, the history of the air masses also had an effect on the effectiveness of the FN. Figure 8 shows an example of two different air mass back trajectories calculated using the HYSPLIT method - Hybrid Single Particle Lagrangian Integrated Trajectory Model (http://www.arl.noaa.gov). Filters 1-8 had similar trajectories that originated from the ocean. These air masses named maritime because according to their back trajectories, they originated over the Ocean about $60 \mathrm{~h}$ before reaching the South Pole station (e.g. note the back trajectory of the air sampled on filter 4 in Fig. 8). In contrast, the air sampled on filters 9-12 had trajectories that spent at least $72 \mathrm{~h}$ over the continent, much longer than the air that was sampled on filters $1-8$. Therefore in this paper we refer to them as continental (e.g. note the back trajectory of the air sampled on filter 10 in Fig. 8).

The differences in the history of the air mass, based on their back trajectory must have had some effect on the FN concentration and activity. As can be seen in Fig. 9, higher FN concentrations were observed for all the rooftop filters that sampled air that had originated from the ocean (1-4

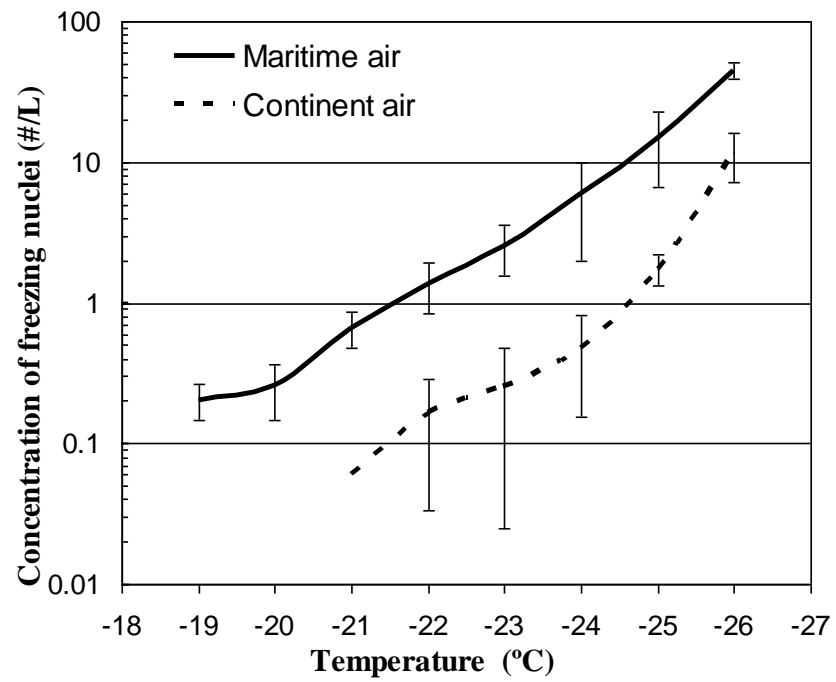

Fig. 9. Comparison between measurements taken on the rooftop based on air trajectory calculations. The solid curve represents ice nuclei concentrations in maritime air mass as measured from filters $1-4$ and 8 . The dashed curve is for ice nuclei concentrations in continental air mass as measured from filters 9-12. See text for definition of maritime and continental air. Bars represent the standard deviation.

and 8) as compared to samples of air that spent much longer time over the continent (filters 9-12). The higher concentrations of FN in maritime air could be caused by anthropogenic pollution emitted from ships and cruises that frequent the coast during the summer (Graf et al., 2010). We cannot rule out the role of bio-aerosols emitted from the coastal water as an important source of FN. It is also clear that the events with high concentrations of FN (filters 1-4, see also Table 3 ) were mostly associated with strong winds.

Although continental air contained lower concentrations of FN than the maritime one, the difference between the elemental compositions of the aerosol particles in these two air masses as measured with ESEM-EDX, was relatively small, with $\mathrm{Al}, \mathrm{Si}, \mathrm{Fe}, \mathrm{Ca}$, more abundance in the former and $\mathrm{Cl}$ and $\mathrm{Na}$ more abundance in the latter (Table 4). The possible explanation for these relatively small differences in elemental composition is the fact that the station is located over $1000 \mathrm{~km}$ away from the coast. Thus air mass that originates from the ocean spent a long time over the land, mixing with continental type aerosols. Furthermore, the elemental composition listed in Table 4 is similar to that found in the Patagonia desert (Gaiero et al., 2007), and is in agreement with the measurements of Parungo et al. (1981), suggesting the transport of mineral dust from this region in South America.

Although we found differences in FN concentrations for different air masses and meteorological conditions we think that it is valuable to obtain an average parametric equation for FN concentrations in such a remote site, something that 


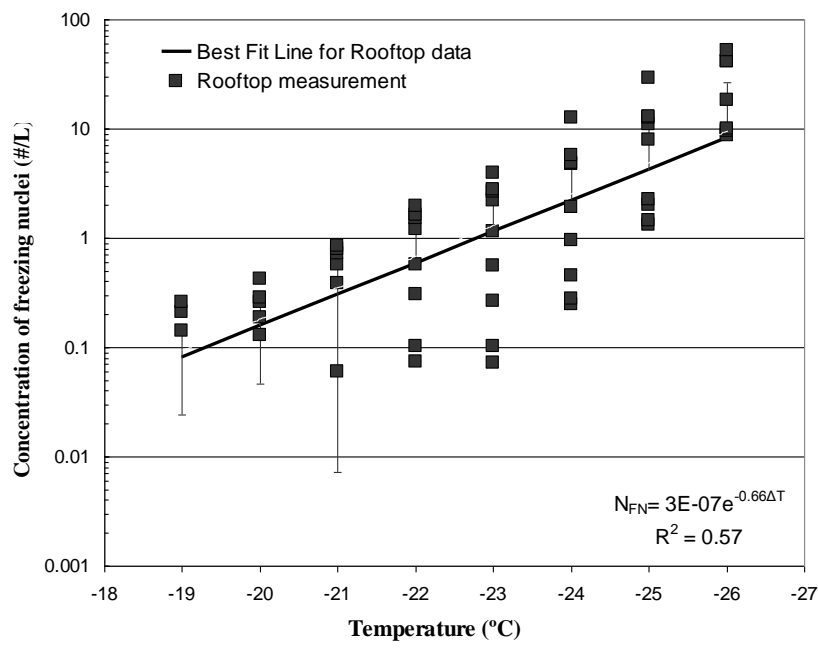

Fig. 10. The concentrations of FN in the air. The equation represents the best fit line to the rooftop data.

Table 4. Frequency of occurrence (\%) of elements in individual particles in maritime and continental air masses.

\begin{tabular}{|c|c|c|}
\hline Elements & Continental & Maritime \\
\hline $\mathrm{AL}$ & 44.4 & 37.4 \\
\hline $\mathrm{Ca}$ & 35.3 & 27.5 \\
\hline $\mathrm{Si}$ & 32.0 & 22.0 \\
\hline $\mathrm{Fe}$ & 23.5 & 18.7 \\
\hline $\mathrm{K}$ & 22.2 & 12.1 \\
\hline $\mathrm{Cu}$ & 21.6 & 11.0 \\
\hline $\mathrm{Mg}$ & 18.3 & 16.5 \\
\hline $\mathrm{F}$ & 15.7 & 8.8 \\
\hline$S$ & 14.4 & 14.3 \\
\hline $\mathrm{Cl}$ & 11.1 & 24.2 \\
\hline $\mathrm{Na}$ & 8.5 & 22.0 \\
\hline $\mathrm{Ti}$ & 3.3 & 1.1 \\
\hline $\mathrm{Zn}$ & 2.0 & 9.9 \\
\hline $\mathrm{Cr}$ & 2.0 & 8.8 \\
\hline $\mathrm{Au}$ & & 4.4 \\
\hline $\mathrm{Ni}$ & & 2.2 \\
\hline $\mathrm{Sn}$ & & 2.2 \\
\hline Mo & & 1.1 \\
\hline $\mathrm{Cd}$ & 3.3 & \\
\hline $\mathrm{P}$ & 0.7 & \\
\hline $\mathrm{Br}$ & 0.7 & \\
\hline $\mathrm{Mn}$ & 0.7 & \\
\hline number of particle & 153 & 91 \\
\hline
\end{tabular}

could be helpful in numerical models. For this purpose all the rooftop measurements were combined and a best fit line was calculated (Fig. 10). The resulting best-fit line is:

$N_{\mathrm{FN}}=3 \times 10^{-7} e^{0.66 \Delta T}$

$N_{\mathrm{FN}}-$ the number concentrations of $\mathrm{FN}\left(\mathrm{L}^{-1}\right)$

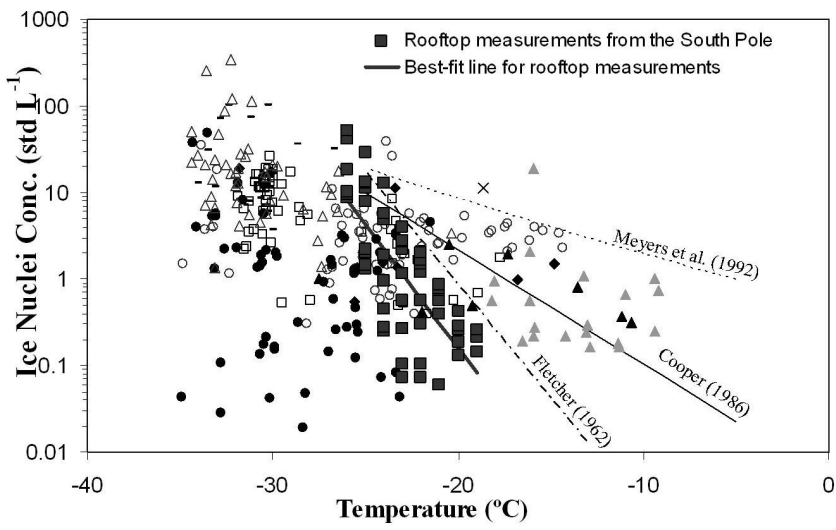

Fig. 11. Ice nuclei concentrations as a function of temperature from DeMott et al. (2010) with the present measurements shown in black squares.

$\Delta T$ - supercooling in ${ }^{\circ} \mathrm{C}(0-T)$

From the figure one can see that ice nucleus concentration of $\sim 1 \mathrm{~L}^{-1}$ is found at $-23^{\circ} \mathrm{C}$, which is a little lower than what Bigg and Stevenson (1970) reported as average concentrations at higher latitudes $\left(\sim 1 \mathrm{~L}^{-1}\right.$ at $\left.-20^{\circ} \mathrm{C}\right)$.

Comparing the FN concentrations obtained from Eq. (2) with previous measurements show that at $-15^{\circ} \mathrm{C}$ the calculated concentrations are somewhat lower than what Bigg (1973) reported from his coastal measurements $\left(\sim 0.015 \mathrm{~L}^{-1}\right)$. On the other hand, at Palmer Station, Saxena and Weintraub (1988) found ice nuclei concentrations of $\sim 1 \mathrm{~L}^{-1}$ at $-18^{\circ} \mathrm{C}$, which are higher than those reported here and by Bigg (1973). There could be a number of reasons for this difference, the most reasonable one is that in the past 37 years the anthropogenic activity in and around Antarctica has increased dramatically, leading to more pollution from ships and other activities (Graf et al., 2010).

Overall the Ice nuclei concentrations that were found in the South Pole station are in agreement with other IN concentrations that were measured in other locations around the globe, as can be seen in Fig. 11. However, the temperature dependence in these data is much stronger than generally found in the data from DeMott et al. (2010). There may be many reasons for such differences that could only be revealed by further research. For example, data were not obtained to determine any association of IN with the presence of larger aerosols, as was inferred to be partly responsible for IN variability at one temperature by DeMott et al. (2010).

\section{Conclusions}

Immersion Freezing Nuclei were measured from samples collected at the South Pole station during late January early February 2009. FN was found to be effective from $-18^{\circ} \mathrm{C}$ 
down to $-27^{\circ} \mathrm{C}$, with concentrations ranging from 0.1 to $53 \mathrm{~L}^{-1}$. The temperature at which $50 \%$ of the drops froze occurred at $-24^{\circ} \mathrm{C}$. Concentration of $1 \mathrm{~L}^{-1}$ was observed at $-23^{\circ} \mathrm{C}$.

The meteorological conditions, such as wind speed or precipitation in addition to the trajectory of the air mass appear to have affected the FN concentrations at the South Pole station. Higher concentrations were found in cases when the air originated from the ocean (maritime). The strongest correlation of FN concentration was found with wind speed. FN concentrations were almost five to nine times higher when the wind increased from 4.4 to $9 \mathrm{~m} \mathrm{~s}^{-1}$.

Using the data, a parametric equation was calculated for the mean concentrations of $\mathrm{FN}$ as a function of temperature for a remote location such as the South Pole station. Since the measurements vary with meteorological conditions, more measurements under different conditions are needed to improve the parametric equation derived here.

Acknowledgements. Thanks are due to Patrick J. Sheridan, from NOAA, Earth System Research Laboratory Global Monitoring Division/GMD-1, for supplying us with additional data from the campaign. We thank Alexei Korolev of Environment Canada for his diligence in collecting the filter measurements and itemizing the data. We would also like to acknowledge Chris Roden and Pat Zmarzly of SPEC Inc. for setting up the filter measurements on the rooftop and on the balloon. The analysis of the data was carried out under the partial support from grants from the Virtual Institute on Aerosol-Cloud Interactions, supported by the HelmholtzGemeinschaft (HGF) and by the German Israeli Foundation (GIF) grant number 1-860-27. We would like to thank Paul DeMott and two anonymous reviewers whose questions and comments helped us improve the paper. The South Pole field project was sponsored by Grant OPP-0337876 to SPEC Incorporated from the US National Science Foundation.

Edited by: E. Weingartner

\section{References}

Argentini, S., Viola, A., Sempreviva, A. M., and Petenko, I.: Summer boundary-layer height at the plateau site of Dome C, Antarctica, Bound.-Lay Meteorol., 115, 409-422, 2005.

Bigg, E. K.: Ice nucleus measurements in remote areas, J. Atmos. Sci., 30, 1153-1157, 1973.

Bigg, E. K.: Comparison of Aerosol at Four Baseline Atmospheric Monitoring Stations, J. Appl. Meteor., 19, 521-533, 1980.

Bigg, E. K.: Long-term trends in ice nucleus concentrations, Atmos. Res., 25, 409-415, 1990.

Bigg, E. K. and Hopwood, S.: Ice Nuclei in the Antarctic, J. Atmos. Sci., 20, 185-188, 1963.

Bigg, E. K. and Stevenson, C. M.: Comparison of ice nuclei in different parts of the world, J. Rech. Atmos., 4, 41-58, 1970.

Bigg, E. K., Gras, J. L., and Evans, C.: Origins of Aitken particles in remote regions of the Southern Hemisphere, J. Atmos. Chem., 1, 203-214, 1984.
Bird, I., Cresswell, G., Humble, J., Norris, I. D., and Bigg, E. K.: Atmospheric Ice Nuclei in high southern latituder, J. Meteorol., 18, 563-564, 1961.

Bundke, U., Nillius, B., Jaenicke, R., Wetter, T., Klein, H., and Bingemer, H.: The Fast Ice Nucleus Chamber FINCH, Atmos. Res., 90, 180-186, doi:10.1016/j.atmosres.2008.02.008, 2008.

Bodhaine, B. A., Dutton, E. G., DeLuisi, J. J., Harris, J. M., Shaw, G. E., Hansen, A. D. A., and Novakov, T.: South Pole aerosol measurements during 1987 in: Atmospheric Aerosols and Nucleation, edited by: Wagner, P. E. and Vali, G., Springer-Verlag, New York, USA, 1988.

Cadle, R. D., Fischer, W. H., Frank, E. R., and Lodge, J. P.: Particles in the Antarctic Atmosphere, J. Atmos. Sci., 25, 100-103, 1968.

Carpenter, E. J., Lin, S., and Capone, D. G.: Bacterial activity in South Pole, Appl. Environ. Microbiol., 66, 4514-4517, 2000.

DeFelice, T. P.: Variations in cloud condensation nuclei at palmer station Antarctica during February 1994, Atmos. Res., 41, 229248, 1996.

DeFelice, T. P., Saxena, V. K., and Yu, S.: On the measurements of cloud condensation nuclei at Palmer Station, Antarctica, Atmos. Environ., 31, 4039-4044, 1997.

DeMott, P. J., Prenni, A. J., Liu, X., Kreidenweis, S. M., Petters, M. D., Twohy, C. H., Richardson, M. S., Eidhammer, T., and Rogers, D. C.: Predicting global atmospheric ice nuclei distributions and their impacts on climate, P. Natl. Acad. Sci. USA., 107, 1121711222,2010

Deshpande, C. G. and Kamra, A. K.: Physical properties of aerosols at Maitri, Antarctica, J. Earth Syst. Sci., 113, 1-25, 2004.

Egan, W. G. and Hogan, A. W.: Meteorological variation of atmospheric optical properties in an antarctic storm, Appl. Optics, 25, 1155-1165, 1986.

Gaiero, D. M., Brunet, F., Probst, J. L., and Depetris, P. J.: A uniform isotopic and chemical signature of dust exported from Patagonia: Rock sources and occurrence in southern environments, Chem. Geo., 238, 107-120, 2007.

Geology.: Map of Antarctica and Southern Ocean, landsat image mosaic of Antarctica (LIMA) project. Retrieved 17 April 2010, available at: http://geology.com/, 2010.

Graf, H.-F., Shirsat, S. V., Oppenheimer, C., Jarvis, M. J., Podzun, R., and Jacob, D.: Continental scale Antarctic deposition of sulphur and black carbon from anthropogenic and volcanic sources, Atmos. Chem. Phys., 10, 2457-2465, doi:10.5194/acp-10-24572010, 2010.

Gras, J. L., Adriaansen, A., Butler, R., Jarvis, B., Magill, P., and Lingen, B.: Concentration and size variation of condensation nuclei at Mawson, Antarctica, J. Atmos. Chem., 3, 93-106, 1985.

Hogan, A. W.: Summer ice crystal precipitation at the South Pole, J. Appl. Meteor., 14, 246-249, 1975a.

Hogan, A. W.: Antarctic aerosols, J. Appl. Meteor., 14, 550-559, $1975 b$.

Hogan, A. W.: Meteorological transport of particulate material to the South Polar Plateau, J. Appl. Meteor., 18, 741-749, 1979.

Hogan, A. W. and Barnard, S.: Seasonal and Frontal Variation in Antarctic Aerosol Concentrations, J. Appl. Meteor., 17, 14581465, 1978.

Hogan, A. W., Barnard, S., Samson, J., and Winters, W.: The Transport of Heat, Water Vapor and Particulate Material to the South Polar Plateau, J. Geophys. Res., 87, 4287-4292, 1982.

Hogan, A. W., Kebschull, K., Townsend, R., Murphey, B., Samson, 
J., and Barnard, S.: Particle concentrations at the South Pole, on meteorological and climatological time scales; Is the difference important?, Geophys. Res. Lett., 11, 850-853, 1984.

Iriondo, M.: Patagonian dust in Antarctica, Quatern. Int., 68-71, 83-86, 2000.

Johnson, M. S., Meskhidze, N., Solmon, F., Gassó, S., Chuang, P. Y., Gaiero, D. M., Yantosca, R. M., Wu, S., and Wang, Y. and Carouge C.: Modeling dust and soluble iron deposition to the South Atlantic Ocean, J. Geophys. Res., 115, D15202, doi:10.1029/2009JD013311, 2010.

Junge, K. and Swanson, B. D.: High-resolution ice nucleation spectra of sea-ice bacteria: implications for cloud formation and life in frozen environments, Biogeosciences, 5, 865-873, doi:10.5194/bg-5-865-2008, 2008.

Klein, H., Haunold, W., Bundke, U., Nillius, B., Wetter, T., Schallenberg, S., and Bingemer, H.: A new method for sampling of atmospheric ice nuclei with subsequent analysis in a static diffusion chamber, Atmos. Res., 96, 218-224, 2010.

Knuth, S. L., Gregory, J. T., Jonathan E. T., and George, A. W.: The Influence of Blowing Snow and Precipitation on Snow Depth Change across the Ross Ice Shelf and Ross Sea Regions of Antarctica, J. Appl. Meteorol. Clim., 49, 1306-1321, 2010.

Kumai, M.: Identification of nuclei and concentrations of chemical species in snow crystals sampled at South Pole, J. Atmos. Sci., 33, 833-841, 1976.

Lawson, R. P., Baker, B. A., Schmitt, C. G., and Jensen, T. L.: An overview of microphysical properties of Arctic clouds observed in May and July during FIRE.ACE, J. Geophys. Res., 106, 14989-15014, 2001.

Lawson, R. P., Baker, B. A., Zmarzly, P., O’Connor, D., Mo, Q., Gayet, J. F., and Shcherbakov, V.: Microphysical and optical properties of ice crystals at South Pole Station, J. Appl. Meteor., 45, 1505-1524, 2006.
Lawson, R. P., Stamnes, K., Stamnes, J., Zmarzly, P., Koskuliks, J., Roden, C., Mo, Q., and Carrithers, M.: Deployment of a Tethered Balloon System for Cloud Microphysics and Radiative Measurements at Ny-Ålesund and South Pole, J. Atmos. Ocean. Tech., doi:10.1175/2010JTECHA1439.1, 2011.

Park, J., Sakurai, H., Vollmers, K., and McMurry, P. H.: Aerosol size distributions measured at the South Pole during ISCAT, Atmos. Environ., 38, 5493-5500, 2004.

Parungo, F., Bodhaine, B., and Bortniak, J.: Seasonal variation in Antarctic aerosol, J. Aerosol Sci., 12, 491-504, 1981.

Saxena, V. K.: Evidence of biogenic nuclei involvement in Antarctic coastal clouds, J. Phys. Chem., 87, 4130-4134, 1983.

Saxena, V. K. and Weintraub, D. C.: Ice forming nuclei concentrations at Palmer Station, Antarctica, in: Atmospheric Aerosols and Nucleation, edited by: Wagner, P. E. and Vali, G., SpringerVerlag, New York, USA, 1988.

Shaw, G. E.: Optical, chemical and physical properties of aerosols over the Antarctic ice sheet, Atmos. Environ., 14, 911-921, 1980.

Su, W. C. and Vincent, J. H.: Towards a general semi-empirical model for the aspiration efficiencies of aerosol samplers in perfectly calm air, J. Aerosol Sci., 35, 1119-1134, 2004.

Vali, G.: Quantitative evaluation of experimental results on the heterogeneous freezing nucleation of supercooled liquids, J. Atmos. Sci., 28, 402-409, 1971.

Warren, S. G. and Hudson, S. R.: Bacterial Activity in South Pole Snow Is Questionable, Appl. Environ. Microbiol., 69, 63406341, 2003. 